\title{
Survey of Nitrogen Isotopes of Lepomis macrochirus (Blue Gill) from Kentucky Lake Reservoir and Ledbetter Creek, Kentucky
}

\author{
Rebecca M. Cripps and George W. Kipphut \\ Department of Biological Sciences \\ \& Hancock Biological Station \\ Murray State University \\ Murray, Kentucky 42071 USA
}

Received: January 4, 2008 Accepted: April 29, 2008

\begin{abstract}
Previous research has shown stable isotope ratios of nitrogen in fish and other animals may vary depending on their food source. Ecologists have had some success in determining feeding and trophic relationships within an ecosystem using stable isotopic ratios. In this study, nitrogen stable isotopic ratios were measured in populations of Lepomis macrochirus (Blue Gill) in Kentucky Lake Reservoir and in a small tributary, Ledbetter Creek, in western Kentucky. The nitrogen isotopic ratios between these populations were statistically different. Even though fish are able to migrate freely between the two environments, the isotopic results suggest that the Lepomis macrochirus in Ledbetter Creek were spending enough time feeding in that environment to alter their isotopic signature. These results may lead to a better understanding of how Lepomis macrochirus utilize both stream and reservoir environments.
\end{abstract}

\section{INTRODUCTION}

Stable isotope ratios in plants and animals have been a topic of great interest to ecologists over the past 25 years. For nitrogen, there is often a measurable isotope ratio difference between adjoining trophic levels [1-3]. For example, there is often a noticeable enrichment of the heavier nitrogen isotope $\left({ }^{15} \mathrm{~N}\right)$ relative to the lighter nitrogen isotope $\left({ }^{14} \mathrm{~N}\right)$ in a predator relative to its prey species [1]. Stable isotopes are fractionated by natural processes within organisms causing small but consistent variations in isotope ratios. For nitrogen, a 3-5 parts per thousand increase in ${ }^{15} \mathrm{~N}$ occurs at each higher trophic level [4]. In animals, a number of factors influence the exact size of the isotopic variation. These include: 1) animals assimilate dietary components with varying efficiencies; 2) metabolic processes within animals can fractionate the isotopes; and 3) animals allocate nutrients in their diet differentially to specific tissues [5]. Research today often involves determining isotope ratios over multiple trophic levels in the ecosystem of interest [2, 6-10].

Not only can the relative trophic levels of an organism be determined from isotopic studies, but isotope ratios have also been helpful in distinguishing between similar organisms living in different environments [3]. For example, an organism feeding in a detrital-based (allochthonous) system may have a different isotopic composition than the same organism feeding in an algal-based (autochthonous) system. In our study we tested whether young Lepomis macrochirus (Blue Gill Sunfish) sampled from a stream (allochthonous system) and a reservoir embayment (autochthonous system) had different stable nitrogen isotope ratios. Lepomis macrochirus is known to inhabit both lake and stream environments in our study area [11]. L. macrochirus tend to move back and forth from stream to lake habitats when the two are connected although it was not known whether the fish feed 


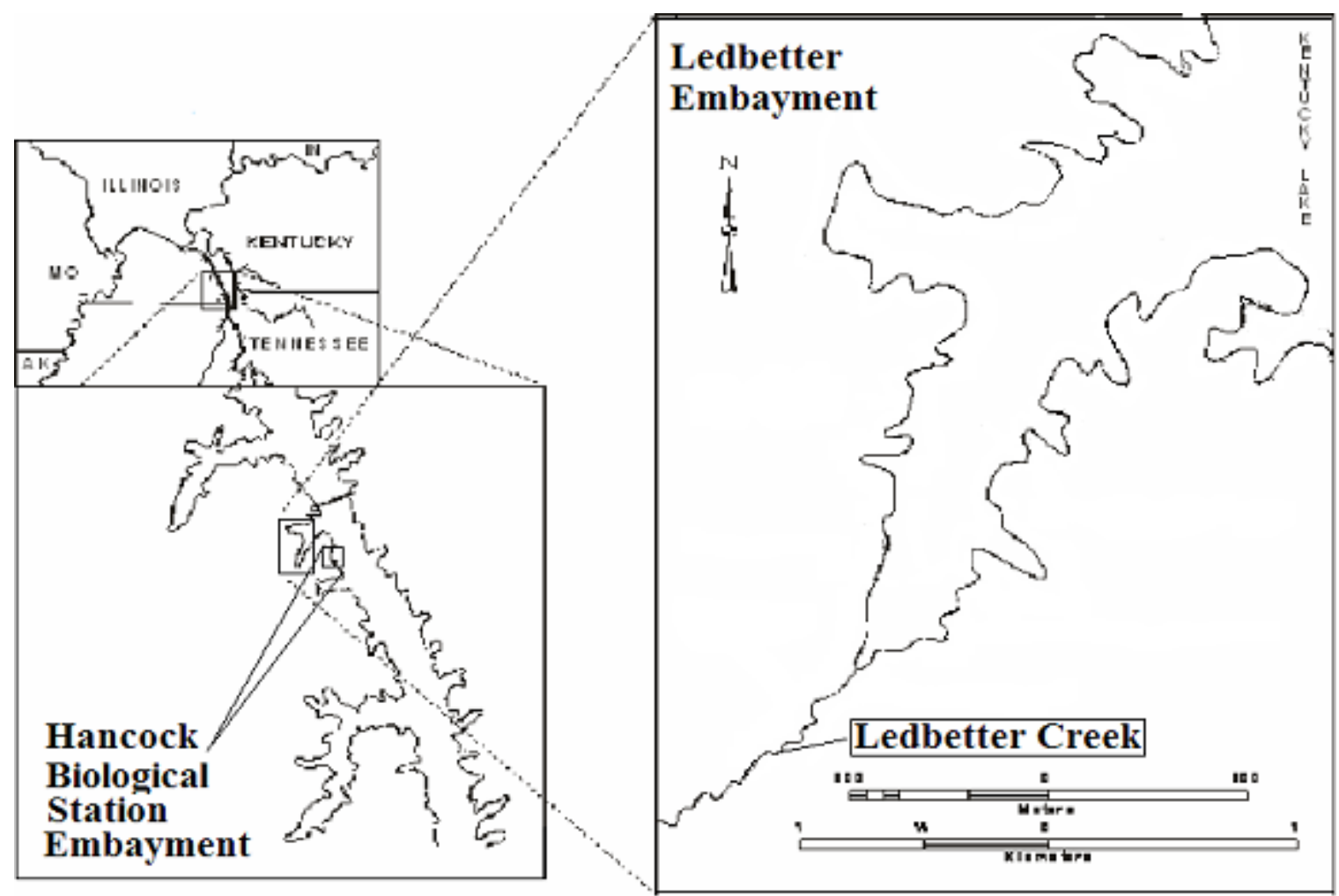

Figure 1. Locations of sampling sites: Fish in Ledbetter Creek were collected approximately 300 m upstream from Kentucky Lake.

preferentially in one system or the other long enough to alter their nitrogen isotopic ratios.

\section{MATERIALS \& METHODS}

L. macrochirus were collected from an embayment on Kentucky Lake Reservoir near the Hancock Biological Station, and from a tributary stream, Ledbetter Creek in western Kentucky (Figure 1). Kentucky Lake is the largest reservoir in the Tennessee River Valley and is classified as an 8th order system. Ledbetter Creek is a $3^{\text {rd }}$ order stream (average discharge $<0.5 \mathrm{~m}^{3} \mathrm{sec}^{-1}$ ). The fish in Ledbetter Creek are able to swim freely to and from Kentucky Lake. $L$. macrochirus are usually absent from Ledbetter Creek during winter months. There are multiple reasons for $L$. macrochirus to seasonally move into stream environments, including avoidance of larger predatory fish. Kentucky Lake and Ledbetter Creek do contain at least two other species of Lepomis besides $L$. macrochirus. These include Lepomis cyanellus (Green Sunfish) and Lepomis microlophus (Red Ear Sunfish). All fish analyzed in our study were positively identified as $L$. macrochirus.

Fish were collected on two separate dates. The Reservoir embayment was sampled on September 15, 2006 and Ledbetter Creek was sampled on November 4, 2006.

At both sites a seine net was used to collect the L. macrochirus. One sample was obtained from each fish collected. Twenty-nine fish were sampled from each site, thus totaling fifty-eight samples overall. Fish collected from Kentucky Lake were selected to be of approximately the same size as those collected from Ledbetter Creek. Specimens were bagged and frozen until samples of tissue could be obtained. For each specimen the standard length $(\mathrm{mm})$ was recorded (Figure 2). A sample "fillet" of lean muscle tissue was cut from each specimen and dried at $40-50^{\circ} \mathrm{C}$ for at least 24 hours. Each dried sample was ground with a mortar and and pestle and 1 $\mathrm{mg}$ samples were weighed for isotopic analysis. Nitrogen isotope ratios were 


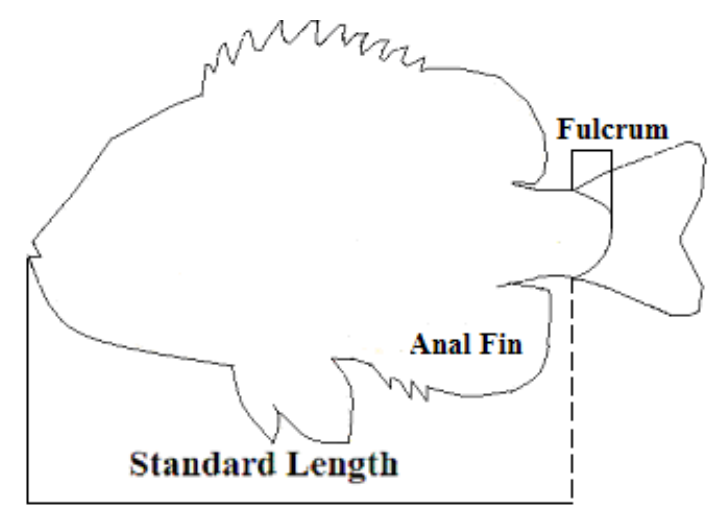

Figure 2: Standard Length measurements for $L$. macrochirus. Measurements were taken from tip of mouth/lips to tip of fulcrum (swollen area above and below base of caudal fin) closest to the anal fin.

measured with a Mass Spectrometer (model: Finnigan Delta Plus XP Isotope Ratio Mass Spectrometer interfaced to an Elemental Combustion System) at the Hancock Biological Station. Nitrogen isotopic ratios $\left({ }^{15} \mathrm{~N} /{ }^{14} \mathrm{~N}\right)$ are reported in parts per thousand $(\%)$ using the standard $\delta$ notation for reporting stable isotope ratios:

$$
\delta^{15} \mathrm{~N} \% \text { o }=\left(\left[\mathrm{R}_{\text {sample }} / \mathrm{R}_{\text {standard }}\right]-1\right) \times 1000
$$

where $\mathrm{R}=$ is the ${ }^{15} \mathrm{~N} /{ }^{14} \mathrm{~N}$ atom ratio of the sample or standard material. Ammonium sulfate, NIST $8547\left(\delta^{15} \mathrm{~N}=+0.4\right)$, was used as the standard reference material.

\section{RESULTS}

The results of the nitrogen isotope ratios for fish collected at the two study sites are summarized in Box and Whisker plots in Figure 3. Plots contain results for all 29 fish from each site. Standard lengths of the sampled fish ranged from $28-48 \mathrm{~mm}$ (fish that were not yet full grown adults). The horizontal line within each box represents the median of the $\delta^{15} \mathrm{~N}$ for each sample set (11.25\%o and $10.24 \%$ o for the Embayment and Creek samples, respectively). The bottom and top of each box represent the first and third quartile, respectively, of each data set. The bottom and top of each whisker represent the $10^{\text {th }}$ and $90^{\text {th }}$ percentiles, respectively, of each data set. Points beyond each whisker represent data outside of these ranges. As indicated in Figure 3, only 4 of 29 fish for each site were in the outlier range. The medians were tested for significance using a paired t-test. The $p$ value of .000143 indicates that the data sets are significantly different.

\section{DISCUSSION}

The two populations of $L$. macrochirus sampled in this study had significantly different nitrogen isotope ratios (Figure 3). It has been seen that allochthonous materials from terrestrial vegetation often differ significantly in signatures of $\delta^{15} \mathrm{~N}$ compared to that of the autochthonous material from algae [4]. Results from Fry [9] were a prime example of the significant differences in $\delta^{15} \mathrm{~N}$ of allochthonous (terrestrial plants) and autochthonous (algae) materials. In Fry's 1991 study, results showed that algae typically had higher $\delta^{15} \mathrm{~N}$ than terrestrial plants in both lake and stream systems [9]. The fish in the reservoir embayment of this study had higher $\delta^{15} \mathrm{~N}$ than fish in the stream environment. There are few other studies to which we can compare our results. However, Fry [9] found that organisms within lake ecosystems tended to have higher $\delta^{15} \mathrm{~N}$ when compared to similar organisms in stream ecosystems. Our results are in agreement with Fry [9] and suggest that the $\delta^{75} \mathrm{~N}$ of the fish are influenced by the different $\delta^{15} \mathrm{~N}$ of food sources available in stream (allochthonous/terrestrial) and reservoir embayment (autochthonous/algae) systems. We believe that the time interval between sampling dates for the two sites 


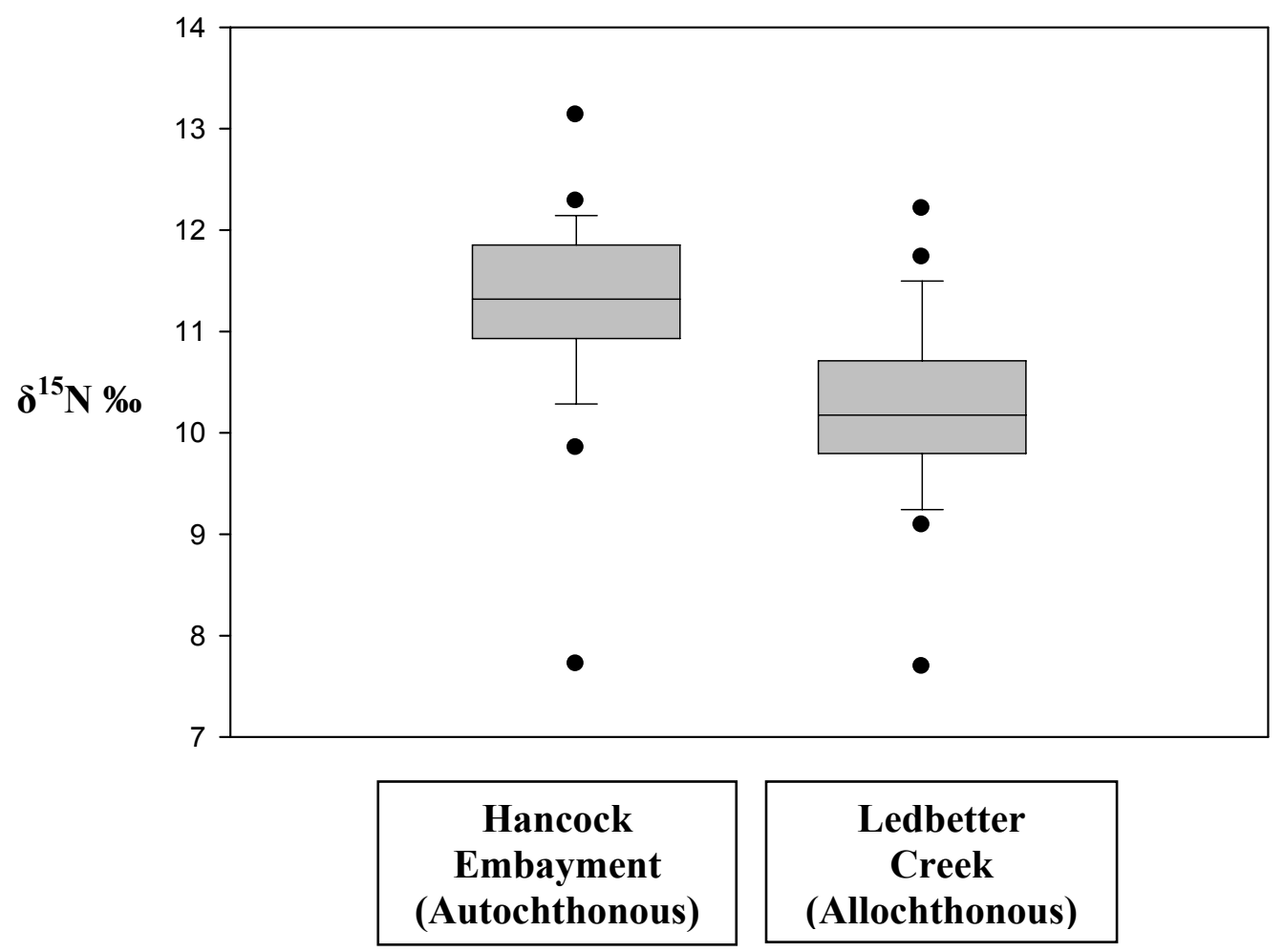

Figure 3. Box and Whisker plots of nitrogen isotope ratios in L. macrochirus. Total samples analyzed were fifty-eight, twenty-nine from each site. Statistical significance was obtained using paired t-test with $\mathrm{p}$ value $=.000143$.

does not significantly affect our conclusions. Maruyama et al. [12] showed that nitrogen in fish muscle tissue was replaced at the rate of $5-20 \%$ per month by metabolic turnover. The half-change period for $8^{15} \mathrm{~N}$ was estimated as being longer than 1 month. Clearly, this could be a consideration in seasonal or longer-term studies and requires more research.

Predator avoidance is a likely reason that small $L$. macrochirus and other species migrate temporarily into small stream environments [13]. Less competition among fewer species of fish inhabiting small streams has also been suggested as a reason for migration [14]. When these fish migrate into the stream system they feed upon the allochthonous materials long enough to alter their $\delta^{15} \mathrm{~N}$ signature to represent the allochthonous materials. Further nitrogen isotopic studies may lead to a better understanding of how and why $L$. macrochirus and other fish utilize both stream and lake environments.
We have two suggestions for further research in this area. In order to minimize variations in fish size and age between sites, only small $L$. macrochirus $(24-48 \mathrm{~mm})$ from the reservoir embayment were utilized in this study. This species can grow to a much larger size in the reservoir environment. Determining the $\delta^{15} \mathrm{~N}$ of larger reservoir fish would better establish whether there is a fundamental difference in the $\delta^{15} \mathrm{~N}$ of the food available to fish in the two environments. We also suggest that analysis of fish gut contents be included in future studies. Such measurements would provide a clearer link between diet and the $\delta^{15} \mathrm{~N}$ of fish tissue.

\section{ACKNOWLEDGEMENTS}

The authors would like to thank Hancock Biological Station for use of facilities and equipment. We also thank Dr. Hwa-Seong Jin and James Ramsey for development of project idea. Additional thanks to James 
Ramsey for assistance in the collection of samples.

\section{REFERENCES}

1. Cabana G.; Rasmussen J. B. 1994. Modeling food chain structure and contaminant bioaccumulation using stable nitrogen isotopes. Nature 372:255-257.

2. Fry B. 1988. Food web structure on Georges Bank from stable C, N, and S isotopic compositions. Limnology and Oceanography 33:1182-1190.

3. Rounick J.S.; Winterbourn M.J. 1986. Stable carbon isotopes and carbon flow in ecosystems. Bioscience 36(3):171177.

4. Dodds W. 2002. Freshwater ecology concepts and environment applications. Academic Press 394-397.

5. Gannes L. Z.; O'Brien D. M.; Martinez del Rio C. 1997. Stable isotopes in animal ecology: assumptions, caveats, and a call for more laboratory experiments. Ecology 78(4):1271-1276.

6. Anderson C.; Cabana G. $2005 . \delta^{15} \mathrm{~N}$ in riverine food webs: effects of $N$ inputs from agricultural watersheds. Canadian Journal of Fisheries and Aquatic Sciences 62:333-340.

7. Ashkenas L. R.; Johnson S. L.; Gregory S. V.; Tank J. L.; Wollheim W. M. 2004. A stable isotope tracer study of nitrogen uptake and transformation in an oldgrowth forest stream. Ecology 85(6):1725-1739.

8. Fry B.; Jeng W.; Scalan R. S.; Parker P. L. 1978. $\delta^{13} \mathrm{C}$ food web analysis of a Texas sand dune community. Geochimica et Cosmochimica Acta 42:1299-1302.

9. Fry B. 1991. Stable isotope diagrams of freshwater food webs. Ecology 72(6):2293-2297.

10. Hicks B. J. 1997. Food webs in forest and pasture streams in the Waikato region, New Zealand: a study based on analyses of stable isotopes of carbon and nitrogen, and fish gut contents. New Zealand Journal of Marine and Freshwater Research 31:651-664.

11. Etnier D. A.; Starnes W. C. 1993. The fishes of Tennessee. The University of Tennessee Press 398-419.
12. Maruyama A.; Yamada Y.; Rusuwa B.; Yuma M. 2001. Change in stable nitrogen isotope ratio in the muscle tissue of a migratory goby, Rhinogobius $s p$. , in a natural setting. Canadian Journal of Fisheries and Aquatic Sciences 58(11):2125-2128.

13. Turner A. M.; Mittelbach G. G. 1990. Predator avoidance and community structure: interactions among piscivores, planktivores, and plankton. Ecology 71(6):2241-2254.

14. Werner E. E.; Hall D. J. 1979. Foraging efficiency and habitat switching in competing sunfishes. Ecology 60(2):256-264.

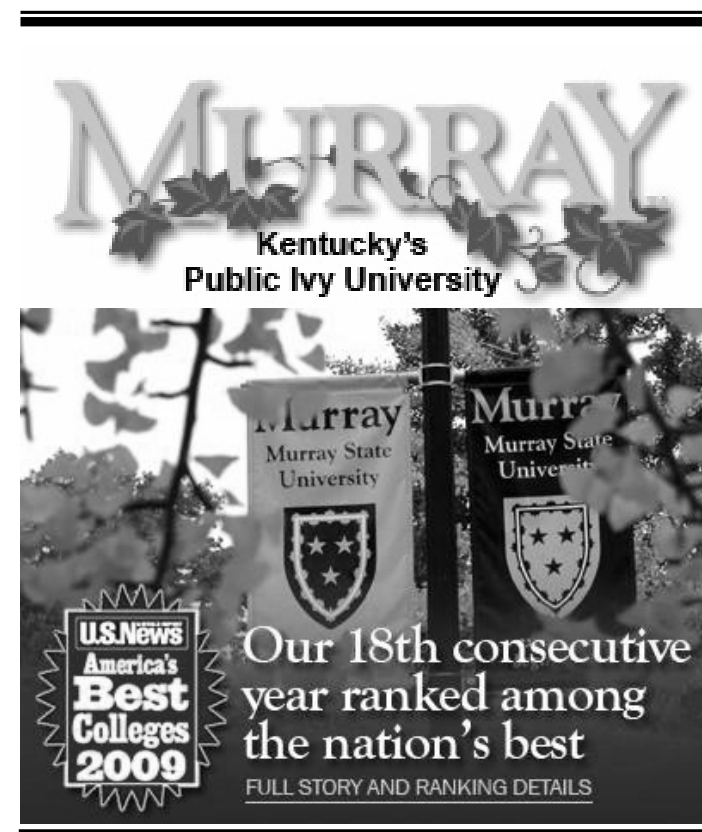

Murray State University is home to 10,304 students. As one of the nation's best public universities, Murray attracts students who are seeking a great education in a personalized, college town setting.

Murray State University

113 Sparks Hall

Murray, KY 42071

wWw.murraystate.edu 

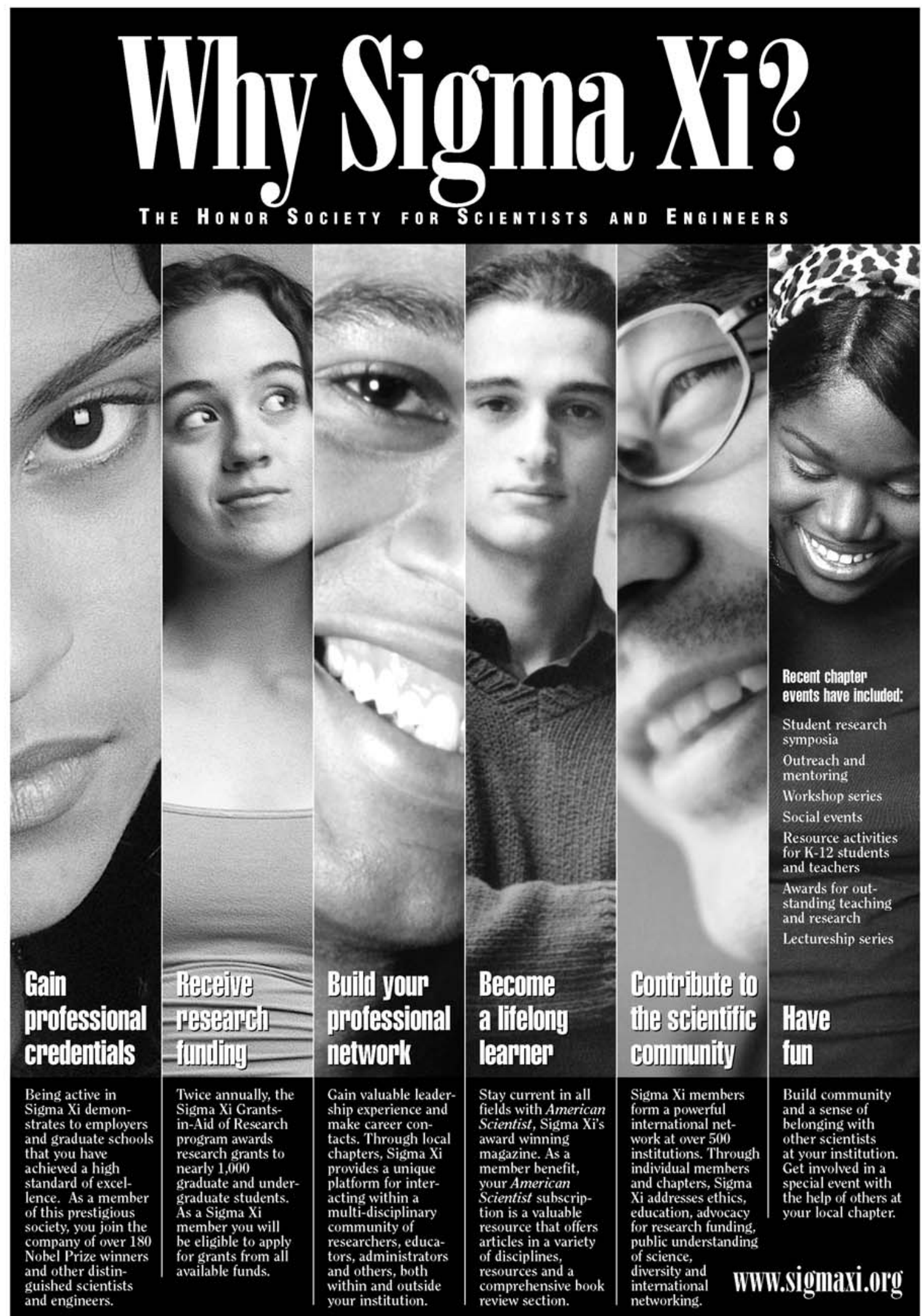

Sigma Xi, The Scientific Research Society • 98 Alexanter Drive • P.O. Box 13975 • Research Triangle Park, NC 27709 • 919-549-4691 • 800-243-6534 